\title{
Molecular imaging in Alzheimer's disease: new perspectives on biomarkers for early diagnosis and drug development
}

\author{
Agneta Nordberg*
}

\begin{abstract}
Recent progress in molecular imaging has provided new important knowledge for further understanding the time course of early pathological disease processes in Alzheimer's disease (AD). Positron emission tomography (PET) amyloid beta (A $\beta$ ) tracers such as Pittsburgh Compound $B$ detect increasing deposition of fibrillar $A \beta$ in the brain at the prodromal stages of $A D$, while the levels of fibrillar $A \beta$ appear more stable at high levels in clinical AD. There is a need for PET ligands to visualize smaller forms of $A \beta$, oligomeric forms, in the brain and to understand how they interact with synaptic activity and neurodegeneration. The inflammatory markers presently under development might provide further insight into the disease mechanism as well as imaging tracers for tau. Biomarkers measuring functional changes in the brain such as regional cerebral glucose metabolism and neurotransmitter activity seem to strongly correlate with clinical symptoms of cognitive decline. Molecular imaging biomarkers will have a clinical implication in AD not only for early detection of AD but for selecting patients for certain drug therapies and to test diseasemodifying drugs. PET fibrillar A $\beta$ imaging together with cerebrospinal fluid biomarkers are promising as biomarkers for early recognition of subjects at risk for $A D$, for identifying patients for certain therapy and for quantifying anti-amyloid effects. Functional biomarkers such as regional cerebral glucose metabolism together with measurement of the brain volumes provide valuable information about disease progression and outcome of drug treatment.
\end{abstract}

*Correspondence: Agneta.K.Nordberg@ki.se

Karolinska Institutet, Alzheimer Neurobiology Center, Karolinska University, Hospital Huddinge, Novum $5^{\text {th }}$ floor, 14186 Stockholm, Sweden

\section{Introduction}

Alzheimer's disease (AD) is characterized by a slow continued deterioration of cognitive processes. The first symptoms of episodic memory disturbances might be quite subtle. When the patient is assessed for memory problems the disease has most probably been ongoing in the brain for several years and has most probably induced nonrepairable disturbances of important functional neuronal networks and loops of the brain. It is a challenge to test whether some of these changes could be reversed or slowed down with early drug treatment.

The recent progress in $\mathrm{AD}$ research has provided new knowledge for further understanding the pathology processes of AD that precede the onset of clinical disease by many years. It is still an open question why some people can cope with $\mathrm{AD}$ brain pathology better than others. Do they have greater capacity of neuronal compensation? Is there ongoing neurogenesis in the brain? The resistance toward increased pathological burden especially observed in highly educated subjects might be a sign of increased brain plasticity as well as greater cognitive reserve [1].

Since Dr Alois Alzheimer first described the AD disease, amyloid beta $(A \beta)$ has played a central role in $A D$ pathology. It has not yet been proven that $A \beta$ is the primary causative factor of $\mathrm{AD}$. A puzzling observation from autopsy $A D$ brain studies has been the weak correlation between fibrillar $\mathrm{A} \beta$ load in the brain and cognition while the amount of neurofibrillary tangles significantly correlates with the cognitive status and duration of dementia [2-4]. The effects of $A \beta$ in the clinical stages of $\mathrm{AD}$ are most probably mediated by the presence of neurofibrillary tangles in the brain [5]. In addition, a sequential cascade of events including oxidative stress reactions, inflammatory processes and neurotransmitter and receptor dysfunction most probably contributes to the impairment of cognitive function [6].

Molecular imaging techniques have rapidly developed during recent years. This development not only allows one to measure brain structural changes in patients 
(atrophy, volume changes and cortical thickness) by magnetic resonance imaging, but also to visualize and quantify brain pathology (fibrillar $A \beta$, tau, activated microglia and astrocytosis) as well as functional changes (cerebral glucose metabolism, neurotransmitter and neuroreceptor activity) by positron emission tomography (PET) (Table 1). Molecular imaging thus provides important insight into the ongoing pathological processes in $\mathrm{AD}$ in relation to clinical symptoms and disease progression. An important step forward has been in vivo imaging of $\mathrm{A} \beta$ pathology in $\mathrm{AD}$ patients. Although the histopathological confirmation of diagnosis at autopsy is important, it reflects the end stage of a disease that may have been ongoing for decades.

The new molecular imaging techniques provide possibilities to develop early diagnostic biomarkers for early detection of $\mathrm{AD}$ at preclinical stages, as well as for monitoring effects of drug therapy. Recent research has thus also changed the view on incorporating biomarkers into the standardized clinical diagnosis of $\mathrm{AD}$ as suggested by Dubois and colleagues $[7,8]$ and the recommendations from the National Institute on Aging-Alzheimer Association workgroups on diagnostic guidelines for $\mathrm{AD}$ $[9,10]$.

\section{Amyloid imaging in Alzheimer's disease patients} Among the first A $\beta$ PET tracers was Pittsburgh Compound $\mathrm{B}\left({ }^{11} \mathrm{C}-\mathrm{PIB}\right)$ when $16 \mathrm{AD}$ patients were initially scanned in Sweden [11]. The high ${ }^{11} \mathrm{C}$-PIB retention observed in cortical and subcortical brain regions of mild AD patients compared with age-matched healthy subjects has consistently been confirmed with ${ }^{11} \mathrm{C}$-PIB in several other studies (for a review see [12-14]). Several other $\mathrm{A} \beta$ PET tracers have also been tested in $\mathrm{AD}$ and control patients $[12,15]$ although so far ${ }^{11} \mathrm{C}$-PIB is the most explored. ${ }^{18} \mathrm{~F}$-labeled tracers will probably be more suitable for use in the clinic, with their longer half-life. ${ }^{18} \mathrm{~F}$-FDDNP was the first ${ }^{18} \mathrm{~F}$-PET tracer used for visualizing $A \beta$ plaque in $A D$ patients [16], showing lower binding affinity to $A \beta$ plaques than ${ }^{11} \mathrm{C}$-PIB but also suggested to bind to neurofibrillary tangles $[16,17]$. The ${ }^{18} \mathrm{~F}$-labeled A $\beta$ PET tracers ${ }^{18} \mathrm{~F}$-flutemetamol, ${ }^{18} \mathrm{~F}$-florbetapir and ${ }^{18} \mathrm{~F}$-florbetaben have shown promising results in $\mathrm{AD}$ patients [18-20].

The PET A $\beta$ tracers quantify fibrillar $A \beta$ in the brain by binding in the nanomolar range to the $A \beta$ peptide [21]. The in vivo ${ }^{11} \mathrm{C}$-PIB retention correlates with ${ }^{3} \mathrm{H}-\mathrm{PIB}$ binding as well as levels of $A \beta$ measured in autopsy $A D$ brain tissue [22-25]. ${ }^{18}$ F-florbetapir PET imaging has also been shown to correlate with the presence of $A \beta$ amyloid at autopsy [26], as well as ${ }^{18} \mathrm{~F}$-flutemetamol PET imaging to amyloid measured in cortical biopsies [27].

A still unknown factor is the relationship between fibrillar $\mathrm{A} \beta$ (plaques) and soluble $\mathrm{A} \beta$ oligomers. Presently
Table 1. Pathological and functional biomarkers in Alzheimer's disease

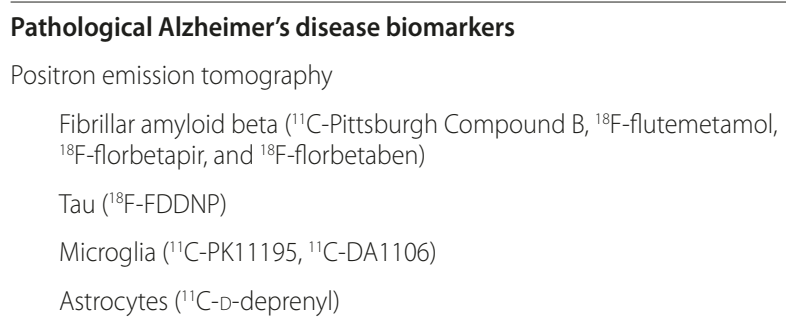

Functional Alzheimer's disease biomarkers

Positron emission tomography

Cerebral glucose metabolism $\left({ }^{18} \mathrm{~F}-\mathrm{FDG}\right)$

Neurotransmitter activity (for example, ${ }^{11} \mathrm{C}-\mathrm{CFT},{ }^{11} \mathrm{C}-\mathrm{PMP}$ )

Neuroreceptors (for example, ${ }^{11} \mathrm{C}$-raclopride, ${ }^{18} \mathrm{~F}$-alanserine, ${ }^{11} \mathrm{C}$-nicotine)

Functional magnetic resonance imaging, spectroscopy

Single-photon emission computed tomography (cerebral blood flow)

there is no information on how the smaller soluble $A \beta$ oligomers, which are known for triggering synaptic dysfunction [28-30], can be visualized in vivo in man with the presently available $A \beta$ tracers. It is therefore a challenge to try to develop PET tracers that can visualize these smaller forms of $A \beta$ in the brain, although the probably lower content of oligomers in $\mathrm{AD}$ brains compared with fibrillar $A \beta$ might be a limiting factor. The soluble $\mathrm{A} \beta$ oligomers are important since they probably can induce and interfere with the neurotransmission in the brain $[30,31]$.

\section{Longitudinal PET amyloid studies in Alzheimer's disease patients}

There are still few longitudinal studies of A $\beta$ PET imaging in $\mathrm{AD}$ patients. These studies are important to understand the rate of accumulation of amyloid in the brain and are important for evaluation of intervention in antiamyloid drugs. A 2-year follow-up study with ${ }^{11} \mathrm{C}$-PIB in $\mathrm{AD}$ patients revealed at group level consistent stable fibrillar $\mathrm{A} \beta$ levels in the brain [32]. Two additional 1-year and 2-year follow-up studies confirmed these observations $[33,34]$ as well as a recent 5-year follow-up PET study of the first imaged PIB PET cohort [35]. In the latter study it was evident at the individual level that increased, stable and decreased PIB retention were observed and the disease progression was reflected in significant decline in cerebral regional cerebral glucose metabolism (rCMRglc) and cognition [35]. In a recent 20-month follow-up study, Villemagne and colleagues reported a $5.7 \%$ increase in fibrillar $A \beta$ in $A D$ patients [36]. The longitudinal imaging studies mainly support the 
assumption that the $\mathrm{A} \beta$ levels in the $\mathrm{AD}$ brain reach a maximal level at the early clinical stage of the disease, although both increase and decline in later stages of the disease cannot be excluded $[12,37,38]$.

\section{Amyloid imaging in mild cognitive impairment patients}

${ }^{11} \mathrm{C}$-PIB PET studies in mild cognitive impairment (MCI) patients have revealed a bimodal distribution. Both high $\left(\mathrm{PIB}^{+}\right)$and low $\left(\mathrm{PIB}^{-}\right)$retention of the PET tracer has been demonstrated [39,40]. $\mathrm{PIB}^{+} \mathrm{MCI}$ patients seem to have a greater risk to convert to $\mathrm{AD}$ after clinical followup compared with PIB- $^{-}$MCI patients [39,41,42]. Figure 1 illustrates high ${ }^{11} \mathrm{C}$-PIB retention in a $\mathrm{MCI}$ patient $\left(\mathrm{PIB}^{+}\right)$ who later converted to $\mathrm{AD}$ in comparison with a nonconverting $\mathrm{MCI}$ patient $\left(\mathrm{PIB}^{-}\right)$. $\mathrm{PIB}^{+} \mathrm{MCI}$ patients show comparably high ${ }^{11} \mathrm{C}-\mathrm{PIB}$ retention to $\mathrm{AD}$ patients (Figure 1). We recently observed a significant increase in brain ${ }^{11} \mathrm{C}$-PIB retention in early MCI patients when rescanned after 3 years [35]. The MCI patients also showed a decrease in rCMRglc while they remained stable in cognitive function at follow-up [35]. Jack and colleagues [34] and Villemagne and colleagues [36] have also reported annual changes in ${ }^{11} \mathrm{C}$-PIB retention. These findings support a continuous increase in $A \beta$ load in the early stage of prodromal AD [35] (Figure 2).

\section{Amyloid imaging in older subjects without cognitive impairment}

High $A \beta$ has been measured in older cognitive normal controls (for a review see [43]). The reported percentage of positive A $\beta$ PET scans varies from 10 to $50 \%$ between different cohorts of studied older people without cognitive impairment [44,45]. A possible explanation for variation in percentage of $A \beta$ PET-positive cognitive normal subjects could be age but also genetic background (APOE genotype). A $\beta$ alone most probably does not account for the decline in memory in older people. Further longitudinal studies are needed to investigate to what extent these $A \beta$-positive older people with normal cognition will later convert to $\mathrm{AD}$ [46]. In a recent longitudinal study of 159 older subjects with normal cognition and $\mathrm{PIB}^{+}$, PET showed a greater risk for developing symptomatic $\mathrm{AD}$ within 2 to 5 years compared with $\mathrm{PIB}^{-}$subjects [47].

\section{Relationship between brain amyloid and cerebrospinal fluid biomarkers}

There is a strong inverse correlation between accumulations of fibrillar $A \beta$ in the brain as measured by ${ }^{11} \mathrm{C}$-PIB and levels of $A \beta_{1-42}$ in cerebrospinal fluid (CSF) [39,48-55]. An inverse correlation between ${ }^{11} \mathrm{C}$-PIB retention and CSF $A \beta_{1-42}$ has been demonstrated in prodromal $A D$ $(\mathrm{MCI})$ earlier than changes in functional parameters

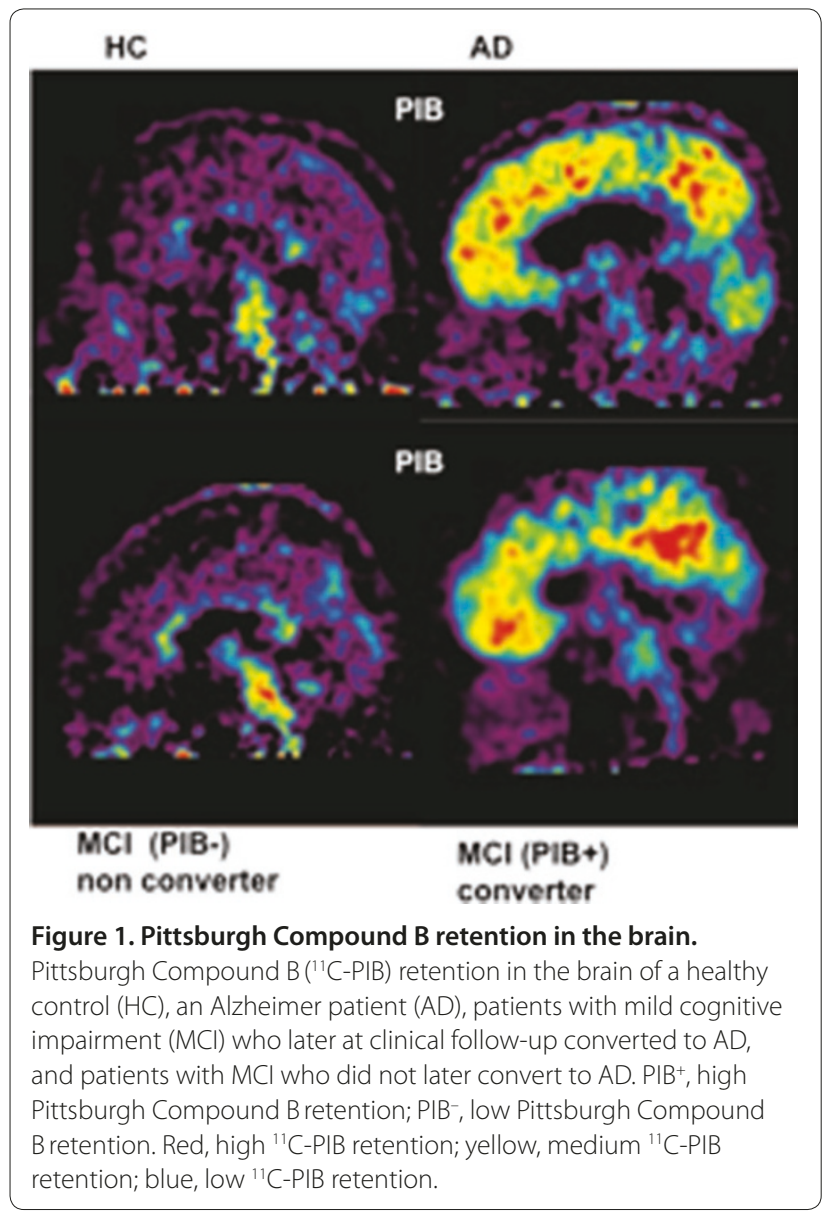

(cerebral glucose metabolism, cognition) [54] (Figure 2). Figure 3 illustrates the inverse relationship between $A \beta$ in the brain and the CSF as analyzed with statistical parametric mapping cluster analysis. A positive relationship has also been observed between ${ }^{11} \mathrm{C}$-PIB retention and levels of CSF tau and p-tau $[39,50,51,54]$. Which of the biomarkers are most sensitive to detect the earliest pathological signs of the disease is still unclear.

Some data suggest that ${ }^{11} \mathrm{C}$-PIB PET imaging detects amyloid pathology prior to CSF biomarkers [39,49,54]. Soluble $A \beta$ oligomers might be the most pathogenic in $A D$. An interesting observation is therefore that $A D$ patients with the APP arctic mutation show no fibrillar $A \beta$ in the brain (PIB-negative) but a reduction of $A \beta_{42}$ in CSF as well as a reduction in cerebral glucose metabolisms by PET [56].

\section{Imaging of inflammatory processes in Alzheimer's disease brain}

Inflammatory processes have been suggested to cause the pathological processes of AD [57,58]. Amyloid has been observed to mobilize and activate microglia [59]. Activated microglia are found in autopsy brain tissue at 


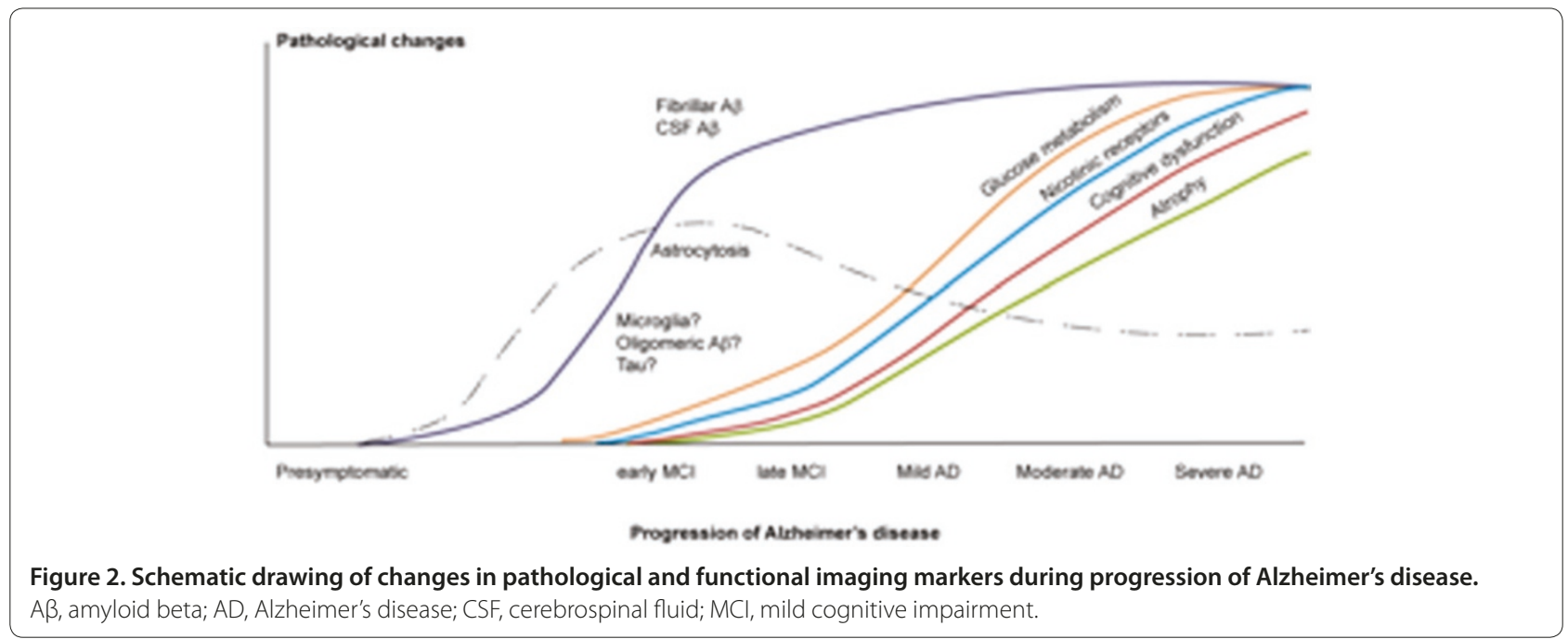

sites of aggregated $\mathrm{A} \beta$ deposition of $\mathrm{AD}$ patients. The peripheral benzodiazepine receptor PET tracer ${ }^{11} \mathrm{C}-(\mathrm{R})$ PK11195 has been used for measuring the transition of microglia from a resting state to an activated state in the brain. An increase in ${ }^{11} \mathrm{C}$-(R)-PK11195 binding was described by Cagnin and colleagues in the temporoparietal, cingulated and entorhinal cortices of $\mathrm{AD}$ patients as a sign for strong microglia activation compared with controls [60]. Edison and colleagues demonstrated high cortical ${ }^{11} \mathrm{C}-(\mathrm{R})$-PK11195 binding with reciprocal negative correlation with cognitive performance in $\mathrm{AD}$ patients [61]. In some other studies, a lower level of microglia activation was observed in mild $\mathrm{AD}$ and $\mathrm{MCI}[62,63] .{ }^{11} \mathrm{C}-\mathrm{DAA}-1106$ is a new peripheral benzodiazepine PET tracer that has shown increased binding in several brain regions including the frontal, parietal, temporal cortices and striatum of AD patients compared with age-matched controls [64].

Activated astrocytes participate in the inflammatory processes occurring around the $A \beta$ plaques. An increased number of astrocytes have been measured in autopsy brain tissue from $\mathrm{AD}$ patients, especially those with the Swedish APP mutation [65]. A positive correlation has been observed between ${ }^{3} \mathrm{H}$-PIB binding and GFAP immunoreactivity in autopsy AD brain tissue [25]. It is assumed that synaptic activity might be coupled to utilization of energy through an interaction between astrocytes and neurons where the astrocytes take up glucose and release lactate to neurons [66].

$\mathrm{N}$ - $\left[{ }^{11} \mathrm{C}\right.$-methyl $]$-L-deuterodeprenyl $\left({ }^{11} \mathrm{C}\right.$-DED) has been shown to irreversibly bind to the enzyme monoaminooxidase $\mathrm{B}$ expressed in reactive astrocytes. ${ }^{11} \mathrm{C}$-DED has therefore been tested as a PET ligand for measurement of activated astrocytes. Increased ${ }^{11} \mathrm{C}$-DED binding was demonstrated in the brain of patients with Creutzfeldt-Jacob disease [67]. We have recently observed by PET an increased ${ }^{11} \mathrm{C}$-DED binding in the cortical and subcortical brain regions of $\mathrm{MCI}$ patients compared with $\mathrm{AD}$ patients and controls [68]. These observations suggest that astrocytosis might be a very early event in the time course of pathological processes in $\mathrm{AD}$ (Figure 2). Further studies are needed to explore the relationship between $A \beta$ and inflammatory processes in the early stages of $\mathrm{AD}$.

\section{Imaging of functional changes in Alzheimer's disease brain}

\section{Brain glucose metabolism}

2- $\left[{ }^{18} \mathrm{~F}\right]$-fluoro-2-deoxy-D-glucose $\left({ }^{18} \mathrm{~F}\right.$-FDG $)$ has been widely used both in research and clinically for measurement of regional changes in rCMRglc in AD [10]. A reduction of rCMRglc is often observed in the parietal, temporal, frontal and posterior cingulate cortices. The decline in rCMRglc is more regional specific compared with the increased ${ }^{11} \mathrm{C}$-PIB retention in large areas of the $\mathrm{AD}$ brain [11,32]. The hypometabolism is often more severe in early-onset $\mathrm{AD}$ compared with late-onset $\mathrm{AD}$, while no difference in regional ${ }^{11} \mathrm{C}$-PIB retention has been observed between early-onset and late-onset AD [69]. ${ }^{11} \mathrm{C}$-PIB PET seems to detect prodromal AD at an earlier disease stage and better separates between MCI subtypes (amnestic versus nonamnestic) than ${ }^{18} \mathrm{~F}-\mathrm{FDG}[39,58,70]$. The decline in rCMRglc follows, in contrast to PIB, the clinical progression of $\mathrm{AD}$ and shows a strong correlation with changes in cognition [32,35,58,70]. Figure 3 illustrates the correlation between rCMRglc and episodic memory (Rey Auditory Verbal Learning) and between ${ }^{11} \mathrm{C}$-PIB and episodic memory (Rey Auditory Verbal Learning) as analyzed with statistical parametric mapping analysis. The ${ }^{18} \mathrm{~F}-\mathrm{FDG}$ uptake shows more brain regional specific clusters compared with ${ }^{11} \mathrm{C}-\mathrm{PIB}$ [54]. 
PIB

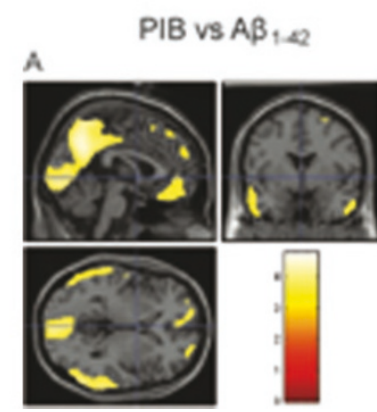

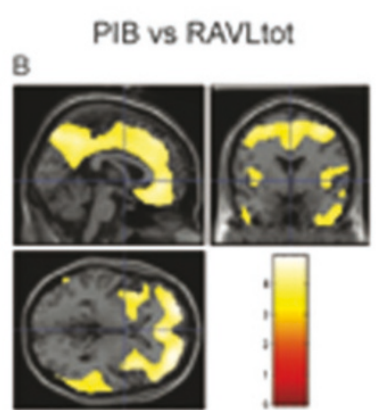

rCMRglc

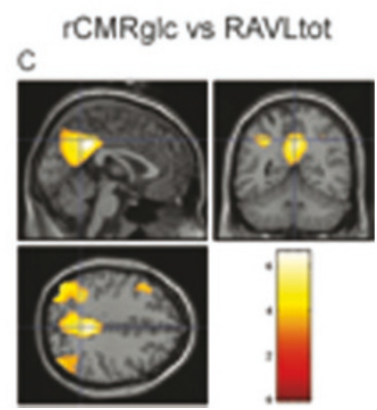

Figure 3. Positron emission tomography measurements, cerebrospinal fluid amyloid beta $\mathbf{1 - 4 2}$ and episodic memory scores. Statistical parametric mapping analysis showing clusters with significant covariance between positron emission tomography measurements versus levels of cerebrospinal fluid (CSF) amyloid beta 1-42 (A $\beta_{1-42}$ ) and episodic memory scores measured by means of Rey Auditory Verbal Learning (RAVLtot) tests, using data from Alzheimer's disease and mild cognitive impairment patients, at threshold $P<0.001$, uncorrected for multiple comparisons. (a) Areas with significant covariance between Pittsburgh Compound B ( $\left.{ }^{11} \mathrm{C}-\mathrm{PIB}\right)$ retention and concentrations of $\mathrm{A} \beta_{1-42}$ in CSF. (b) Clusters with significant covariance between ${ }^{11} \mathrm{C}$-PIB retention and scores in RAVLtot tests. (c) Significant clusters of covariance between regional cerebral glucose metabolism (rCMRglc) and scores in RAVLtot tests. Data from [54].

\section{Neurotransmitter and neuroreceptor imaging}

Several neurotransmitters are impaired in AD, especially the cholinergic system but also the dopaminergic and serotonergic neurotransmitter. Several PET tracers have been developed and tested for measuring the different neurotransmitters, enzymes and various subtypes of receptors in $\mathrm{AD}$ patients [10]. PET tracers are available for studying dopaminergic, serotonergic and cholinergic systems [12] (Table 1). The cholinergic neurotransmission has so far been the focus for clinical AD therapy. It is therefore worth mentioning that decreases in nicotinic receptors have been demonstrated by PET in AD patients using ${ }^{11} \mathrm{C}$-nicotine [71] and ${ }^{18}$ F-fluoro-A-85380 ( $\alpha 4$ nicotinic receptors) [72]. The extent of reduction in ${ }^{11} \mathrm{C}$-nicotine binding correlated with the reduction in level of attention of the AD patients [71]. Presently there is a great interest to develop selective PET tracers for imaging of the $\alpha 7$ nicotinic receptors in the brain since these receptors interact with $A \beta$ and might therefore be a new target for AD therapy [73].

\section{Imaging biomarkers and drug development}

Recent progress in molecular imaging and biomarkers indicates that subtle pathological changes indicative for AD disease might be detected decades prior to clinical diagnosis of AD. Differences in the time course are observed between pathological and functional AD imaging biomarkers (Figure 2). PET imaging allows measurement of pathological processes such as deposition of fibrillar $A \beta$ plaques, levels of activated microglia and astrocytosis. There is a need for further exploration of PET tracers visualizing inflammatory processes that might occur at very early disease states (Figure 2). Similarly, there is a great need for PET tracers visualizing the accumulation of $\mathrm{A} \beta$ oligomers in different stages of $\mathrm{AD}$ (Figure 2). Preclinical data for the new promising PET ligand THK 523 for in vivo tau imaging have recently been presented [74]. Additional PET studies are needed to predict with more accuracy the time course for changes in neurotransmitter function including the nicotinic receptors. Brain atrophy changes (magnetic resonance imaging) correlate closely with cognitive decline and disease progression but less with amyloid load in the brain $[14,20,75]$.

The rapid development of molecular imaging will be important not only for early diagnostic biomarkers and early detection of $\mathrm{AD}[7-9,46]$ but also to select patients for certain drug therapies and to identify diseasemodifying therapies and testing in clinical trials (Table 2). PET imaging biomarkers could thereby play an important role in identifying patients with elevated risk of developing $\mathrm{AD}$. In addition, fibrillar $\mathrm{A} \beta$ imaging could (together with CSF $A \beta_{42}$ ) serve as an inclusion criterion as well as a primary outcome in phase 2 and a secondary outcome in phase 3 drug trials. Measurement of rCMRglc and magnetic resonance imaging atrophy changes are probably most useful for predicting the clinical outcomes of drug therapy.

The multi-tracer PET concept offers unique opportunities in drug trials to study pathological as well as functional processes and to relate these processes in the brain to CSF biomarkers and cognitive outcomes (Figure 4). There is now an increased interest to introduce different biomarkers into clinical trials in $\mathrm{AD}$ patients [76], which will be important for all drug candidates in the pipeline for AD trials [77]. Long-term treatment with cholinesterase inhibitors in $\mathrm{AD}$ patients has shown significant correlation between the degree of inhibition 


\section{Table 2. Clinical implications of molecular imaging in Alzheimer's disease}

To increase the understanding of pathophysiological mechanisms

To increase the understanding of time course of disease progression

To understand the differences in time course between pathology and functional changes

To develop diagnostic markers that can predict rate of progression

To enable selection of Alzheimer's disease patients to certain therapy

To measure brain changes after short-term and long-term therapeutic intervention that correlate with clinical symptoms

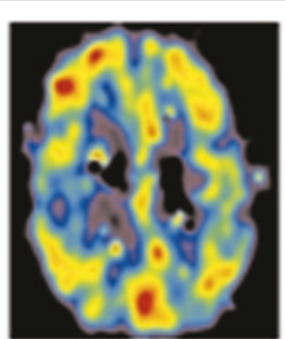

${ }^{11}$ C.PMP

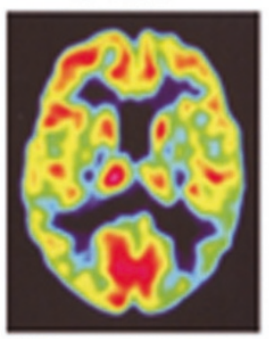

"C-nicotine

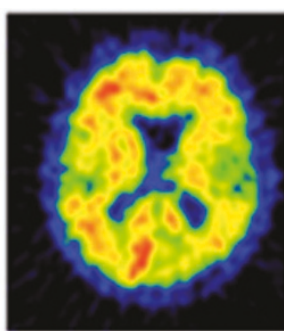

"C.PIB

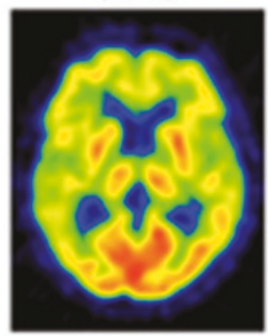

${ }^{13}$ F.FDG

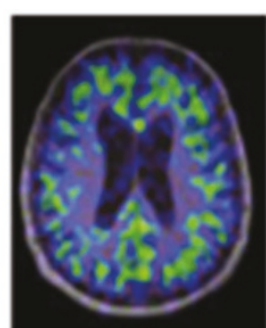

"C-Deprenyl

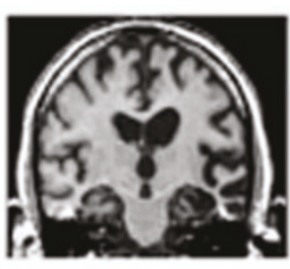

MRI

\section{CSF}

bicmarkers

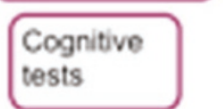

Drug treatment

Figure 4. Multi-tracer positron emission tomography concept to study pathological and functional processes in the brain. Multi-positron emission tomography tracer concept applied in drug trials combined with atrophy studies (magnetic resonance imaging (MRI)), cerebrospinal fluid (CSF) biomarkers and cognitive testing. ${ }^{11} \mathrm{C}$-PMP, acetylcholinesterase; ${ }^{11} \mathrm{C}-\mathrm{PIB}$, amyloid; ${ }^{11} \mathrm{C}$-deprenyl, astrocytosis; ${ }^{11} \mathrm{C}-$-nicotine, nicotinic receptors; ${ }^{18} \mathrm{~F}-\mathrm{FDG}$, 2-[18 $\left.\mathrm{F}\right]$-fluoro-2-deoxy-D-glucose metabolism. Red, high activity; yellow, medium activity; blue, low activity.

of acetylcholinesterase in the brain, the number of nicotinic receptors, rCMRglc and clinical outcome of treatment measured as attentional test performances [78-82]. To evaluate the effect of new disease-modifying therapeutics, imaging of fibrillar amyloid, activated microglia, astrocytosis, tau in addition to rCMRglc and structural brain changes should be applied to determine whether anti-amyloid strategies may clear the amyloid plaques from the brain but also slow down disease progression. A few PET studies in AD patients have shown reduction of brain $\mathrm{A} \beta$ measured by ${ }^{11} \mathrm{C}-\mathrm{PIB}$ following anti-amyloid treatment $[81,83,84]$ but the disease-modifying effects still have to be proven.

\section{Abbreviations}

$A \beta$, amyloid beta; AD, Alzheimer's disease; ${ }^{11} \mathrm{C}-\mathrm{DED}, \mathrm{N}-\left[{ }^{11} \mathrm{C}\right.$-methyl]-L-

deuterodeprenyl; ${ }^{11} \mathrm{C}-\mathrm{PIB}$, Pittsburgh Compound B; CSF, cerebrospinal fluid; ${ }^{18}$ F-FDG, 2-[18 F]-fluoro-2-deoxy-D-glucose; MCl, mild cognitive impairment; PET, positron emission tomography; rCMRglc, regional cerebral glucose metabolism.

\section{Competing interests}

AN is an investigator in clinical trials sponsored by Novartis AB, Jansen-Cilag, Torrey Pines Therapeutics, GSK, Wyeth and Bayer; served on an advisory board for Elan, Pfizer, GSK, Novartis AB, Lundbeck AB, and GE Health Care; served on an advisory board for Elan, Pfizer, GSK, Novartis AB, Lundbeck AB, Merck and GE Health Care; received honorarium for lectures from Novartis AB, Pfizer, Jansen-Cilag, Merck AB, Ely Lilly and Bayer; and received research grants from Novartis AB, Pfizer, GE Health Care and Johnson \& Johnson.

\section{Acknowledgements}

Support was provided by the Swedish Research Council (Project 05817), the regional agreement on medical training and clinical research (ALF) between Stockholm County Council and Karolinska Institutet, Swedish Brain Power, the Swedish Brain Foundation, The Karolinska Institutet Strategic Neuroscience Program, Knut and Alice Wallenberg Foundation. MSci Ruiqing Ni is acknowledged for her assistance with Figure 2.

Published: 2 December 2011

\section{References}

1. Stern Y: Cognitive reserve. Neuropsychologia 2009, 47:2015-2028.

2. Guannalopoulos P, Herrmann FR, Bussière T, Bouras C, Kövari E, Perl DP, Morrison JH, Gold G, Hof PR: Tangles and neuron number but not amyloid load predict cognitive status in Alzheimer's disease. Neurology 2003, 60:1495-1500.

3. Ingelsson M, Fukumoto H, Newell KL, Growdon JH, Hedley-Whyte ET, Frosch MP, Albert MS, Hyman BT, Irizarry MC: Early A $\beta$ accumulation and progressive synaptic loss, gliosis, and tangle formation in AD brain. Neurology 2004, 62:925-931.

4. Nelson PT, Braak H, Markesbery WR: Neuropathology and cognitive 
impairment in Alzheimer's disease: a complex but coherent relationship. J Neuropathol Exp Neurol 2009, 68:1-14.

5. Bennet DA, Schneider JA, Wilson RS, Bienas JL, Arnold SE: Neurofibrillary tangles mediate the association of amyloid load with clinical Alzheimer disease and level of cognitive function. Arch Neurol 2004, 61:378-384.

6. Mattson MP: Pathways towards and away from Alzheimer's disease. Nature 2004, 430:631-639.

7. Dubois B, Feldman HH, Jacova C, Dekosky ST, Barberger-Gateau P, Cummings J, Delacourte A, Galasko D, Gauthier S, Jicha G, Meguro K, O'brien J, Pasquier F, Robert P, Rossor M, Salloway S, Stern Y, Visser PJ, Scheltens P: Research criteria for the diagnosis of Alzheimer's disease: revising the NINCDS-ADRDA criteria. Lancet Neurol 2007, 6:734-746.

8. Dubois B, Feldman HH, Jacova C, Cummings JL, Dekosky ST, BarbergerGateau P, Delacourte A, Frisoni G, Fox NC, Galasko D, Gauthier S, Hampel H, Jicha GA, Meguro K, O'Brien J, Pasquier F, Robert P, Rossor M, Salloway S, Sarazin M, de Souza LC, Stern Y, Visser PJ, Scheltens P: Revising the definition of Alzheimer's disease: a new lexicon. Lancet Neurol 2010, 9:1118-1127.

9. McKann GM, Knopman DS, Chertkow H, Hyman BT, Jack CR, Kawas CH, Klunk WE, Koroshetz WJ, Manly JJ, Mayeux R, Mohs RC, Morris JC, Rossor MN, Scheltens P, Carillo MC, Thies B, Weinstraub S, Phelps CH: The diagnosis of dementia due to Alzheimer's disease: recommendations from the National Institute on Aging-Alzheimer's Association workgroups on diagnostic guidelines for Alzheimer's disease. Alzheimers Dement 2011, 7:263-269.

10. Albert MS, DeKosky ST, Dickson D, Dubois B, Feldman HH, Fox NC, Gamst A, Holtman DM, Pedersen RC, Snyder PJ, Carillo MC, Thies B, Phelps CH: The diagnosis of mild cognitive impairment due to Alzheimer's disease. Recommendations from the National Instutte on Aging-Alzheimer's Association workgroups on diagnostic guidelines for Alzheimer's disease. Alzheimers Dement 2011, 7:270-279.

11. Klunk W, Engler H, Nordberg A, Wang Y, Blomqvist G, Holt DP, Bergström $M$, Savitcheva I, Huang GF, Estrada S, Ausen B, Debnath MS, Barletta J, Price JC, Sandell J, Lopresti BJ, Wall A, Koivisto P, Antoni G, Mathis CA, Långström B: Imaging of brain amyloid in Alzheimer's brain with Pittsburgh Compound-B. Ann Neurol 2004, 55:306-319.

12. Nordberg A, Rinne JO, Kadir A, Långström B: The use of PET in Alzheimer's disease. Nat Rev Neurol 2010, 6:78-87.

13. Sojkov J, Resnick SM: In vivo human amyloid imaging. Curr Alzheimer Res 2011, 8:366-372.

14. Herholz K, Ebmeier K: Clinical amyloid imaging in Alzheimer's disease. Lancet Neurol 2011, 10:667-670.

15. Nordberg A: PET imaging in Alzheimer's disease. Lancet Neurol 2004 3:519-527.

16. Shoghi-Jadid K, Small GW, Agdeppa ED, Kepe V, Ercoli LM, Siddarth P, Read S, Satyamurthy N, Petric A, Huang SC, Barrio JR: Localization of neurofibrillary tangles and beta-amyloid plaques in the brain of living patients with Alzheimer's disease. Am J Geriatr Psychiatry 2002, 10:24-35.

17. Thompson PW, Ye L, Morgenstern JL, Sue L, Beach TG, Judd DJ, Shipley NJ, Libri V, Lockhart A: Interaction of the amyloid tracer FDDNP with hallmark Alzheimer's pathologies. J Neurochem 2009, 109:623-630.

18. Rowe CC, Ackerman U, Browne W, Mulligan R, Pike KL, O'Keefe G, TochonDanguy H, Chan G, Berlangieri SU, Jones G, Dickinson-Rowe KL, Kung HP, Zhang W, Kung MP, Skovronsky D, Dyrks T, Holl G, Krause S, Friebe M, Lehman L, Lindemann S, Dinkelborg LM, Masters CL, Villemagne VL: Imaging of amyloid beta in Alzheimer's disease with ${ }^{18} \mathrm{~F}-\mathrm{BAY} 94-917$, a novel PET tracer: proof of mechanism. Lancet Neurol 2008, 7:129-135.

19. Wong DF, Rosenberg PB, Zhou Y, Kumar A, Raymont V, Ravert HT, Dannals RF, Nandi A, Brasić JR, Ye W, Hilton J, Lyketsos C, Kung HF, Joshi AD, Skovronsky DM, Pontecorvo MJ: In vivo imaging of amyloid deposition in Alzheimer's disease using the radioligand $\left[{ }^{18} \mathrm{~F}\right] \mathrm{AV}-45$ (Florbetapir F18). J Nucl Med 2010, 51:913-920

20. Vandenberghe R, Van Laere K, Ivanoiu A, Salmon E, Bastin C, Triau E, Hasselbalch S, Law I, Andersen A, Korner A, Minthon L, Garraux G, Nelissen N, Bormans G, Buckley C, Owenius R, Thurfiell L, Farrar G, Brooks DJ: ${ }^{18} \mathrm{~F}$-flutemetamol amyloid imaging in Alzheimer's disease and mild cognitive impairment: a phase 2 trial. Ann Neurol 2010, 68:319-329.

21. Klunk WE, Lopresti BJ, Ikonomovic MD, Lefterov IM, Koldamova RP, Abrahamson EE, Debnath ML, Holt DP, Huang GF, Shao L, DeKosky ST, Price $J C$, Mathis CA: Binding of the positron emission tomography compound Pittsburgh compound-B reflects the binding of amyloid beta in Alzheimer's disease but not in in transgenic mice brain. J Neurosci 2005,
25:10598-10606

22. Ikonomovic MD, KlunkWE, Abrahamson EE, Mathis CA, Price JC, Tsopelas ND, Lopresti BJ, Ziolko S, Bi W, Paljug WR, Debnath ML, Hope CE, Isanski BA, Hamilton RL, DeKosky ST: Post-mortem correlates of in vivo PiB-PET amyloid imaging in a typical case of Alzheimer's disease. Brain 2008, 131:1630-1645.

23. Leinonen V, Alafuzoff I, Aalto S, Suotunen T, Savolainen S, Någren K, Tapiola T, Pirttilä T, Rinne J, Jääskeläinen JE, Soininen H, Rinne JO: Assessment of betaamyloid in a frontal cortical brain biopsy specimen and by positron emission tomography with carbon 11-labeled Pittsburgh Compound B. Arch Neurol 2008, 65:1304-1309.

24. Svedberg MM, Hall H, Hellström-Lindahl E, Estrada S, Guan Z, Nordberg A, Långström B: [('1")C]-PIB binding and levels of $A \beta 40$ and $A \beta 42$ in postmortem brain tissue from Alzheimer patients. Neurochem Int 2009, 54:347-357.

25. Kadir A, Marutle A, Gonzalez D, Schöll M, Almkvist O, Mousavi M, Mustafiz T, Darreh-Shori T, Nennesmo I, Nordberg A: Positron emission tomography imaging and clinical progression in relation to molecular pathology in the first Pittsburgh Compound B positron emission tomography patient with Alzheimer's disease. Brain 2011, 134:301-317.

26. Clark CM, Schneider JA, Bedell BJ, Beach TG, Bilker WB, Mintun MA, Pontecorvo MJ, Hefti F, Carpenter AP, Flitter ML, Krautkramer MJ, Kung HF, Coleman RE, Doraiswamy PM, Fleisher AS, Sabbagh MN, Sadowsky CH, Reiman EP, Zehntner SP, Skovronsky DM; AV45-A07 Study Group: Use of florbetapir-PET for imaging beta-amyloid pathology. JAMA 2011, 305:275-283.

27. Wolk DA, Grachev ID, Buckley C, Kazi H, Grady S, Trojankowksi JQ, Hamilton RH, Sherwin P, McLain R, Arnold SE: Association between in vivo 18-labelled flutemetamol amyloid positron emission tomography imaging and in vivo cerebral histopathology. Artch Neurol 2011, 68:1398-1403.

28. Lambert MP, Barlow AK, Chromy BA, Edwards C, Freed R, Liosatos M, Morgan TE, Rozovsky I, Trommer B, Viola KL, Wals P, Zhang C, Finch CE, Krafft GA, Klein $W L$ : Diffusible, nonfibrillar ligands derived from $A \beta_{1-42}$ are potent central nervous system neurotoxins. Proc Natl Acad Sci U S A 1998, 95:6448-6453.

29. Lacor PN, Buniel MC, Chang L, Fernandez SJ, Gong Y, Viola KL, Lambert MP, Velasco PT, Bigio EH, Finch CE, Krafft GA, Klein WL: Synaptic targeting by Alzheimer's-related amyloid beta oligomers. J Neurosci 2004, 24:10191-10200

30. Lacor PN, Buniel MC, Furlow PW, Clemente AS, Velasco PT, Wood M, Viola KL, Klein WL: A $\beta$ oligomer-induced aberrations in synapse composition, shape, and density provide a molecular basis for loss of connectivity in Alzheimer's disease. J Neurosci 2007 , 27:796-807.

31. Bao F, Wicklund L, Lacor P, Klein WL, Nordberg A, Marutle A: Different $\beta$-amyloid oligomer assemblies in Alzheimer brains correlate with age of disease onset and impaired cholinergic activity. Neurobiol Aging 2011, in press.

32. Engler H, Forsberg A, Almkvist O, Blomqvist G, Larsson E, Savitcheva I, Wall A, Ringheim A, Långström B, Nordberg A: Two-year follow-up of amyloid deposition in patients with Alzheimer's disease. Brain 2006, 129:2856-2866.

33. Scheinin NN, Alto S, Koikkalainen J, Lötjönen J, Karrasch M, Kemppainen N, Vitanen M, Någren K, Helin S, Scheinin M, Rinne JO: Follow-up of [ $\left.{ }^{11} \mathrm{C}\right]$ PIB uptake and brain volume in patients with Alzheimer disease and controls. Neurology 2009, 73:1 186-1192

34. Jack CR Jr, Lowe VJ, Weigand SD, Wiste HJ, Senjem ML, Knopman DS, Shiung MM, Gunter UL, Boeve BF, Kemp BJ, Weiner M, Petersen RC: Serial PIB and MRI in normal, mild cognitive impairment and Alzheimer's disease: implication for sequence of pathological events in Alzheimer's disease. Brain 2009, 132:1355-1365.

35. Kadir A, Almkvist O, Forsberg A, Wall A, Engler H, Långström B, Nordberg A: Dynamic changes in PET amyloid and FDG imaging at different stages of Alzheimer's disease. Neurobiol Aging 2012, 33:198.e1-198.e14.

36. Villemagne VL, Pike KE, Chételat G, Ellis KA, Mulligan RS, Bourgeat P, Ackermann U, Jones G, Szoeke C, Salvado O, Martins R, O'Keefe G, Mathis CA, KlunkWE, Ames D, Masters CL, Rowe CC: Longitudinal assessment of AB and cognition in aging and Alzheimer's disease. Ann Neurol 2011, 69:181-192.

37. Nordberg A: Amyloid imaging in Alzheimer's disease. Curr Opin Neurol 2007, 20:398-402.

38. Jack CR Jr, Knopman DS, Jagust WJ, Shaw LM, Aisen PS, Weiner MW, Petersen RC, Trojanowski JQ: Hypothetical model of dynamic biomarkers of the Alzheimer's pathological cascade. Lancet Neurol 2010, 9:119-128. 
39. Forsberg A, Engler $H$, Almkvist $O$, Blomquist $G$, Hagman $G$, Wall A, Ringheim A, Långström B, Nordberg A: PET imaging of amyloid deposition in patients with mild cognitive impairment. Neurobiol Aging 2008, 29:1456-1465.

40. Kemppainen NM, Aalto S, Wilson IA, Någren K, Helin S, Brück A, Oikonen V, Kailajärvi M, Scheinin M, Viitanen M, Parkkola R, Rinne JO: PET amyloid ligand $\left[{ }^{11} \mathrm{C}-\mathrm{PIB}\right]$ uptake is increased in mild cognitive impairment. Neurology 2007 , 68:1603-1606.

41. Okello A, Koivunen J, Edison P, Archer HA, Turkheimer FE, Nagren K, Bullock R, Walker Z, Kennedy A, Fox NC, Rossor MN, Rinne JO, Brooks DJ: Conversion of amyloid positive and negative $\mathrm{MCl}$ to $\mathrm{AD}$ over 3 years. An ${ }^{11} \mathrm{C}$-PIB PET study. Neurology 2009, 73:754-760.

42. Wolk DA, Price JC, Saxton JA, Snitz BE, James JA, Lopez OL, Aizenstein HJ, Cohen AD, Weissfeld LA, Mathis CA, Klunk WE, DeKoskym ST: Amyloid imaging in mild cognitive impairment subtypes. Ann Neurol 2009 65:557-568.

43. Resnick SM, Sojkova J: Amyloid imaging and memory change for prediction of cognitive impairment. Alzheimers Res Ther 2011, 3:3.

44. Nordberg A, Rinne J, Drzezga A, Brooks DJ, Vandenberghe R, Perani D, Almkvist O, Scheinin N, Grimmer T, Okello A, Van Laere K, Hinz R, Carter SF, Kalbe $\mathrm{E}$, Herholz K: PET amyloid imaging and cognition in patients with Alzheimer's disease, mild cognitive impairment $(\mathrm{MCl})$ and healthy controls: a European multicenter study [abstract]. Alzheimers Dement 2009, 5(Suppl 1):P2

45. Jagust WJ, Bandy D, Chen K, Foster NL, Landau SM, Mathis CA, Price JC, Reiman EM, Skovronsky D, Koeppe RA; Alzheimer's Disease Neuroimaging Initiative: The Alzheimer's disease neuroimaging initiative positron emission tomography core. Alzheimers Dement 2010, 6:221-229.

46. Sperling RA, Aisen PS, Becket LA, Bennett DA, Craft S, Fagan AM, Iwatsubo T, Jack CR Jr, Kaye J, Montine TJ, Park DC, Reiman EM, Rowe CC, Siemers E, Stern Y, Yaffe K, Carrillo MC, Thies B, Morrison-Bogorad M, Wagster MV, Phleps CH: Towards defining the preclinical stages of Alzheimer's disease: recommendations from the National Institute on Aging-Alzheimer's Association workgroups on diagnostic guidelines for Alzheimer's disease. Alzheimers Dement 2011, 7:280-292

47. Morris JC, Roe CM, Grant EA, Head D, Storandt M, Goate AM, Fagan AM, Holtzman DM, Mintun MA: Pittsburgh compound B imaging and prediction of progression from cognitive normality to symptomatic Alzheimer disease. Arch Neurol 2009, 66:1469-1475.

48. Fagan AM, Mintun MA, Mach RH, Lee SY, Dence CS, Shah AR, LaRossa GN, Spinner ML, Klunk WE, Mathis CA, de Kosky ST, Morris JC, Holtzman DM: Inverse relation between in vivo amyloid imaging load and cerebrospinal fluid AB42 in humans. Ann Neurol 2006, 59:512-519.

49. Koivunen J, Pirttilä T, Kemppainen N, Aalto S, Herukka SK, Jauhianen AM, Hänninen T, Hallikainen M, Någren K, Rinne JO, Soininen H: PET amyloid ligand $\left[{ }^{11} \mathrm{C}\right] \mathrm{PIB}$ uptake and cerebrospinal fluid beta-amyloid in mild cognitive impairment. Dement Geriatr Cogn Disord 2008, 26:378-383.

50. Jagust WJ, Landau SM, Shaw LM, Trojanowski JQ, Koeppe RA, Reiman EM, Foster NL, Petersen RC, Weiner MW, Price JC, Mathies CA: Relationship between biomarkers in aging and dementia. Neurology 2009, 73:1193-1199.

51. Fagan AM, Mintun MA, Shah AR Aldea P, Roe CM, Mach RH, Marcus D, Morris JC, Holtzman DM: Cerebrospinal fluid tau and ptau181 increase with cortical amyloid deposition in cognitively normal individuals: implications for future clinical trials of Alzheimer's disease. EMBO Mol Med 2009, 1:371-380.

52. Tolboom N, van der Flier WM, Yaqub M, Boellaard R, Verwey NA, Blankenstein $M A$, Windhorst AD, Scheltens P, Lammertsma AA, van Berckel BNM: Relationship of cerebrospinal fluid markers to ${ }^{11} \mathrm{C}-\mathrm{PiB}$ and ${ }^{18} \mathrm{~F}$-FDDNP binding. J Nucl Med 2009, 50:1464-1470

53. Grimmer T, Riemenschneider M, Förstl H, Henriksen G, Klunk WE, Mathis CA Shiga T, Wester HJ, Kurz A, Drzezga A: Beta amyloid in Alzheimer's disease: increased deposition in brain is reflected in reduced concentration in cerebrospinal fluid. Biol Psychiatry 2009, 65:927-934.

54. Forsberg A, Almkvist O, Engler H, Wall A, Långström B, Nordberg A: High PIB retention in Alzheimer's disease is an early event with complex relationship with CSF biomarkers and functional parameters. Curr Alzheimer Res 2010, 7:56-66.

55. Degerman Gunnarsson M, Lindau M, Wall A, Blennow K, Darreh-Shori T, Basu S, Nordberg A, Lannfelt L, Basun H, Kilander L: Pittsburgh Compound B and Alzheimer's disease biomarkers in CSF, plasma and urine: an explorative study. Dement Geriatr Cogn Disord 2010, 29:204-212.
56. Schöll M, Almqvist O, Graff C, Nordberg A: Amyloid imaging in members of a family harbouring the Arctic mutation. Alzheimers Dement 2011, 7(Suppl 1):303.

57. Holmes C, Cunningham C, Zotova E, Woolford J, Dean C, Kerr S, Culliford D, Perry VH: Systemic inflammation and disease progression in Alzheimer disease. Neurology 2009, 73:768-774.

58. Zotova E, Nicoll JAR, Kalaria R, Holmes C, Boche D: Inflammation in Alzheimer's disease: relevance to pathogenesis and therapy. Alzheimers Res Ther 2010, 2:1-9.

59. Block ML, Zecca L, Hong JS: Microglia-mediated neurotoxicity uncovering the molecular mechanisms. Nat Rev Neurosci 2007, 8:57-69.

60. Cagnin A, Brooks DJ, Kennedy AM, Gunn RN, Myers R, Turkheimer FE, Jones T, Banati RB: In-vivo measurement of activated microglia in dementia. Lancet 2001, 358:461-467.

61. Edison P, Archer HA, Gerhard A, Hinz R, Pavese N, Turkheimer FE, Hammers A, Tai YF, Fox N, Kennedy A, Rossor M, Brooks DJ: Microglia, amyloid, and cognition in Alzheimer's disease: an $\left[{ }^{11} \mathrm{C}\right](\mathrm{R}) \mathrm{PK} 11195-\mathrm{PET}$ and $\left[{ }^{11} \mathrm{C}\right] \mathrm{PIB}-\mathrm{PET}$ study. Neurobiol Dis 2008, 32:412-419.

62. Okello A, Edison P, Archer HA, Turkheimer FE, Kennedy J, Bullock R, Walker Z, Kennedy A, Fox N, Rossor M, Brooks D: Microglia activation and amyloid deposition in mild cognitive impairment: a PET study. Neurology 2009, 72:56-62.

63. Wiley CA, Lopresti BJ, Venneti S, Price J, Klunk WE, DeKosky St, Mathis CA: Carbon 11-labeled Pittsburgh Compound B and carbon 11-labeled (R)-PK11195 positron imaging in Alzheimer's disease. Arch Neurol 2009, 66:60-67.

64. Yasuno F, Ota M, Kosaka J, Ito H, Hiquchi M, Doronbekov TK, Nozaki S, Fujimura Y, Koeda M, Asada T, Suhara T: Increased binding of peripheral benzodiazepine receptor in Alzheimer's disease measured by positron emission tomography with [ $\left.{ }^{11} \mathrm{C}\right]$ DAA1106. Biol Psychiatry 2008, 64:835-841.

65. Yu WF, Guan ZZ, Bogdanovic N, Nordberg A: High selective expression of alpha 7 nicotinic receptors on astrocytes in the brains of patients with sporadic Alzheimer's disease and patients carrying Swedish APP 670/671 mutation: a possible association with neuritic plaques. Exp Neurol 2005, 192:215-225.

66. Fuller S, Munch G, Steele M: Activated astrocytes: a therapeutic target in Alzheimer's disease? Expert Rev Neurother 2009, 9:1585-1594.

67. Engler H, Lundberg PO, Ekbom K, Nennesmo I, Nilsson A, Bergström M, Tsukada H, Hartvig P, Långström B: Multi-tracer study with positron emission tomography in Creutzfeldt-Jakob disease. Eur J Nucl Med Mol Imaging 2003, 30:85-95

68. Carter SF, Schöll M, Almkvist $O$, Wall A, Engler $H$, Långström B, Nordberg A Evidence for astrocytosis in prodromal Alzheimer's disease provided by ${ }^{11} \mathrm{C}$-deuterium-L-deprenyl - a multi-tracer PET paradigm combining ${ }^{11} \mathrm{C}-\mathrm{PIB}$ and ${ }^{18} \mathrm{~F}-\mathrm{FDG}$. J Nucl Med 2011, in press.

69. Rabinovici GD, Furst AJ, Alkalay A, Racine CA, O'Neil JP, Janabi M, Baker SL, Agarwal N, Bobasera SJ, Mormino EC, Weiner MW, Gorno-Tempini ML, Rosen HJ, Mimller BL, Jagust WJ: Increased metabolic vulnerability in early-onset Alzheimer's disease is not related to amyloid burden. Brain 2010, 133:512-528.

70. Lowe VJ, Kemp BJ, Jack Jr CR, Senjem M, Weigand S, Shiung M, Smith G, Knopman D, Boeve B, Mullan B, Petersen R: Comparison of ${ }^{18}$ F-FDG and PIB PET in cognitive impairment. J Nucl Med 2009, 50:878-886.

71. Kadir A, Almkvist $O$, Wall A, Långström B, Nordberg A: PET imaging of cortical ${ }^{11} \mathrm{C}$-nicotine binding correlates with the cognitive function of attention in Alzheimer's disease. Psychopharmacology 2006, 188:509-520.

72. Sabri O, Kendziorra K, Wolf H, Gertz HJ, Brust P: Acetylcholine receptors in dementia and mild cognitive impairment. Eur J Nucl Med Mol Imaging 2008, 35(Suppl 1):S30-S45

73. Parri RH, Dineley TK: Nicotinic acetylcholine receptors interact with beta amyloid: molecular, cellular and physiological consequences. Curr Alzheimer Res 2010, 7:27-39.

74. Fodero-Tavoletti MT, Okamura N, Furumoto S, Mulligan RS, Connor AR, McLean CA, Cao D, Rigopoulos A, Cartwright GA, O'Keefe G, Gong S, Adlard PA, Barnham KJ, Rowe CC, Masters CL, Kudo Y, Cappai R, Yanai K, Villemagne $\mathrm{VL}:{ }^{18} \mathrm{~F}$-THK 523-a novel in vivo tau imaging ligand for Alzheimer's disease. Brain 2011, 134:1089-1100.

75. Apostolova LG, Hwang KS, Andrawis JP, Green AE, Babakchanina S, Morra JH, Cummings JL, Toga AW, Trojanowski JQ, Shaw LM, Jack CR Jr, Petersen RC, Aisen PS, Jagust WJ, Koeppe RA, Mathis CA, Weiner MW, Thompson PM: 3D PIB and CSF biomarkers association with hippocampal atrophy in ADNI 
subjects. Neurobiol Aging 2010, 31:1284-1303.

76. Cummings JL: Biomarkers in Alzheimer's disease drug development. Alzheimers Dement 2011, 75:e13-344.

77. Mangialasche F, Solomon A, WInblad B, Mecocci P, Kivipelto M: Alzheimer's disease: clinical trials and development. Lancet Neurol 2010, 9:702-716.

78. Kadir A, Darreh-Shori T, Almkvist O, Wall A, Grut M, Strandberg B, Ringheim A, Eriksson B, Blomquist G, Långström B, Nordberg A: PET imaging of the in vivo acetylcholinesterase activity and nicotine binding in galantaminetreated patients with AD. Neurobiol Aging 2008, 28:1201-1217.

79. Kadir A, Darreh-Shori T, Almkvist O, Wall A, Långström B, Nordberg A: Changes in brain $\left({ }^{11} \mathrm{C}\right)$-nicotine binding sites in patients with mild Alzheimer's disease following rivastigmine treatment as assessed by PET. Psychopharmacology (Berl) 2007, 191:1005-1014.

80. Darreh-Shori T, Kadir A, Almkvist O, Grut M, Wall A, Blomquist G, Eriksson B, Långström B, Nordberg A: Inhibition of acetylcholinesterase in CSF versus brain assessed by ${ }^{11} \mathrm{C}-\mathrm{PMP}$ PET in AD patients treated with galantamine. Neurobiol Aging 2008, 29:168-184.

81. Kadir A, Andreasen N, Almkvist O, Wall A, Forsberg A, Engler H, Hagman G, Lärksäter M, Winblad B, Zetterberg $H$, Blennow K, Långström B, Nordberg A: Effect of phenserine on brain functional activity and amyloid in AD. Ann Neurol 2008, 63:621-631.
82. Keller C, Kadir A, Forsberg A, Porras O, Nordberg A: Long-term effects of galantamine treatment on functional activities as measured by PET in ALzheiner's disease patients. J Alzheimer Dis 2011, 24:109-123.

83. Rinne JO, Brooks DJ, Rossor MN, Fox NC, Bullock R, Klunk WE, Mathis CA, Blennow K, Barakos J, Okello AA, Rodriguez Martinez de Liano S, Liu E, Koller M, Gregg KM, Schenk D, Black R, Grundman M: "1'C-PIB PET assessment of change in fibrillar amyoid-beta load in patients with Alzheimer's disease treated with bapineuzumab: a phase 2 double-blind, placebo-controlled ascending-dose study. Lancet Neurol 2010, 9:363-372.

84. Ostrowitzki S, Deptula D, Thurfell L, Barkhof F, Bohrmann B, Brooks DJ, Klunk WE, Ashford E, Yoo K, Xu ZX, Loetscher H, Santarelli L: Mechanism of amyloid removal in patients with Alzheimer's disease treated with gantenerumab. Arch Neurol 2011, in press.

doi:10.1186/alzrt96

Cite this article as: Nordberg A: Molecular imaging in Alzheimer's disease: new perspectives on biomarkers for early diagnosis and drug development. Alzheimer's Research \& Therapy 2011, 3:34. 